\title{
Ensuring Curriculum Relevance in Vocational Education and Training: Epistemological Perspectives in a Curriculum Research Project
}

\author{
Hilde Hiim* \\ Oslo and Akershus University College, Institute of Vocational Teacher Education, \\ Kunnskapsveien 55, 2007 Kjeller, Norway
}

Received: 11.05.2016; Accepted: 19.12.2016; Published: 26.04.2017

\begin{abstract}
This article addresses challenges regarding relevance in vocational education and training (VET) curricula. Recent research on Norwegian VET shows that the educational content is not sufficiently related to the students' needs for qualification in the actual vocations. I will present a new curriculum research project aimed at investigating and improving the vocational relevance in Norwegian VET. An important part of the project is to investigate epistemological perspectives on how vocational knowledge is constituted and developed, and consequences for the curriculum. The article presents results from these epistemological investigations. I will argue that the relevance problem relates to a one-sided rationalist epistemology in which a main idea is that vocational knowledge consists of theoretical principles and procedures to be applied in practical situations. This idea influences educational traditions and structures, and leads to a separation between theoretical and practical subjects and learning arenas. From a pragmatic epistemological perspective, it can be argued that vocational knowledge is contextual and holistic, and consists of complex wholes of physicality, motor skills, intellectual understandings, values, and verbalized concepts. To ensure curriculum relevance, a curriculum is needed in which authentic practical work is the base, and subjects are integrated with students' practical work experience.
\end{abstract}

Keywords: VET, Vocational Education and Training, VET in Schools, Curriculum Development, Experiential Learning, Vocational Preparation

\footnotetext{
${ }^{*}$ Corresponding author: hilde.hiim@hioa.no
}

ISSN: 2197-8646

http://www.ijrvet.net 


\section{Introduction}

Recent curriculum research in Norwegian vocational education and training (VET) has pointed towards major challenges in vocational education. A core problem is that the educational content is not sufficiently relevant to the needs for qualifications in the actual vocations. Students complain that they lose sight of the vocation for which they wish to qualify. Vocational firms complain that vocational students are not properly qualified (Dahlback, Hansen, Haaland, \& Sylte, 2011; Hansen \& Haaland, 2015; Hiim, $2013,2015)$. The results from various projects indicate that close collaboration and the establishment of an appropriate infrastructure between vocational schools and vocational work enterprises are preconditions for improving curricula and learning (Nyen \& Tønder, 2012; Vibe, Frøseth, Hovdehaugen \& Markussen, 2012). However, significant structural and educational issues present challenges to such improvement.

The Norwegian VET is organised in a $2+2-$ model, with two school years followed by two apprenticeship years. The school-based part consists of nine broad programmes (e.g. construction, crafts and design, social and health care work). The curriculum in the school-based component consists of general academic subjects, general vocational subjects, and practical exercises in school workshops. However, the subjects and exercises are often poorly related to the actual vocations. The curriculum in the apprenticeship part often consists primarily of practical work. There is often a lack of coherence between different learning arenas - the classroom, the school workshop, and the workplace - and between subjects. The curriculum is split into theoretical subjects and corresponding learning arenas, and practical subjects and corresponding arenas. Variations in these problems are common in many VET models (Heggen, Smeby, \& Vågan, 2015; Nyen \& Tønder, 2012). In Norway, there is a high dropout rate in VET that could be related to a lack of relevance in the curriculum, but more research on this possible relationship is needed (Hiim, 2015).

A main task in vocational education is to develop a curriculum that gives students the opportunity to develop vocational knowledge in an occupation for which they wish to qualify. A relevant curriculum is a curriculum that provides the students with this opportunity. An important epistemological question is then: What is vocational knowledge (i.e., how is it constituted and developed)? The problems in Norwegian VET, as in other VET models, can be understood from an epistemological perspective. Norwegian VET students do not have sufficient opportunities to develop vocational knowledge in their chosen vocation. A main reason is that the curriculum is not based on an adequate understanding of how vocational knowledge is constituted and developed. In this article, I will question basic epistemological assumptions that seem to underlie the curriculum in Norwegian VET. The educational structures and the curriculum seem to be based on the ideas that vocational knowledge is a "sum" of different academic and vocational subjects, and consists of the ability to apply general knowledge in specific situations. Vocational knowledge can, therefore, be developed in theoretical and practical arenas separately. I will investigate the concept of vocational knowledge in light of rationalist, pragmatic, and critical epistemologies, and in light of Dreyfus and Dreyfus' (1986) and Schön's $(1983,1988)$ work on vocational and professional knowledge and education. The 
aim of the investigation is to clarify what vocational knowledge is, to establish an epistemological understanding of how a vocationally relevant curriculum can be developed, and to determine what the main obstacles may be.

At Oslo and Akershus University College, we are in an initial phase of an extensive research project aimed at developing knowledge about how to ensure curriculum relevance in VET programmes. The project is based on findings from earlier research that I will present briefly in the next section. The new project involves thirty vocational teachers who are enrolled in an in-service master's programme in vocational pedagogy, instructors from vocational firms, and a group of twelve vocational teacher educators who are also university researchers. A main approach is educational action research in the form of teacher research. Educational action research can be defined as:

Studies that include systematic collaboration in planning, carrying out, evaluation and critical analysis of educational, teaching and learning processes, with the aim of improving the quality of these processes and of developing and documenting new knowledge on education, teaching and learning (Hiim, 2007, p. 101).

In educational action research, curriculum research is seen as a kind of practitioner research that should be conducted by professional teachers (Hiim, 2016; Kemmis, 2012; Zeichner, 2002). The vocational teachers, who represent different vocational programmes, will conduct independent action research projects in their own practises, aimed at developing vocationally relevant curricula in their programmes in collaboration with their students, teacher colleagues, and instructors in actual firms. The projects will be documented in master's theses that will be an important part of the overall documentation of results from the project.

In addition to action research, different forms of quantitative and qualitative research approaches and methods (e.g. interviews and questionnaires) will also be used in the project to investigate how different stakeholders see and experience challenges concerning vocational relevance and the development of vocational knowledge in VET programmes. Important stakeholders include vocational students, apprentices, teachers, instructors, and school leaders. All the different subprojects are aimed at throwing light upon the main question:

How can vocationally relevant curricula be developed in vocational programmes?

In other words - how can we develop a curriculum in vocational education that gives students the opportunities to develop vocational knowledge in a vocation for which they wish to qualify? To answer these questions, epistemological investigations of how vocational knowledge is constituted and developed are important. The aim in this article is to contribute, with an epistemological conceptual framework, to development and research on vocationally relevant curriculum in our project. This framework may also be of interest to other researchers in VET.

I will first present briefly some primary results from an earlier curriculum research project in VET that throw light upon the relevance problem. Our new project builds on 
these results. Then, I will investigate the question of relevancy through epistemological analyses of vocational knowledge. In the final discussion section, I will summarize what we can learn from the epistemological analyses about how curriculum relevance and students' opportunities to develop vocational knowledge can be stimulated and organized, and what important obstacles exist.

\section{Prior Research}

Results from a previous curriculum research project indicate that students in the schoolbased part of Norwegian VET do not believe that they have sufficient opportunities to develop vocational knowledge in their chosen occupations, nor are the vocational teachers satisfied with the opportunities given by the educational structure and curriculum framework. Like the new project, the prior research project also combined action research with qualitative interviews and questionnaires (Dahlback et al., 2011; Hansen \& Haaland, 2015; Hiim, 2013, 2015). The results from the project show that many students get no work life practice in vocations they are interested in during their first year, even if the formal curriculum encourages placement periods in vocational firms. According to the students, the lack of practical experience makes it difficult for them to make informed vocational choices. It also makes it difficult for them to understand the vocational school subjects; the vocational teachers affirm this dilemma. The teachers emphasize that the regional and local educational authorities leave all the responsibility for placement periods and other kinds of cooperation between vocational schools and firms to the individual teachers, and that the system often prevents, rather than facilitates, this kind of cooperation. Students who do get the opportunity of work practice report that the quality varies greatly, and the learning outcome can be quite limited. The teachers say that the division of the curriculum into many different vocational and academic subjects makes it difficult to relate the content systematically to the actual vocations. Correspondingly, the students express that they do not see the connection between the subjects and the vocations. These results are supported by other research (Nyen \& Tønder, 2012; Vibe et al., 2012).

Many of the vocational teachers in this project conducted action research where they tried to develop a more practice-based, integrated curriculum in cooperation with vocational firms. The results were quite promising, and some key principles that came out of the projects can be briefly outlined. The results indicated that cooperation between schools and work life on the curriculum is crucial to students' vocational learning and should be institutionalized, not left to individual teachers. Counselling on choice of occupation in the initial, school-based part of VET programmes is important, and should involve instructors and workers in vocational firms. These workers and instructors have updated information about their respective vocations and may also serve as role models for students. Another precondition for a vocationally relevant curriculum has to do with analysing work demands, core competences, and the need for qualifications in the actual vocations. Cooperation between vocational teachers and instructors on this kind of analysis will secure the relevance of concrete educational content. This cooperation 
should be related to preparations for placement periods, guidance during these periods, and work afterwards. Lectures, assignments, and work in the school workshop should be systematically related to placement periods. Students' practical work experiences can be the basis of work in school, and the integration of subjects with these experiences seems to be a core principle for students' development of vocational knowledge (Hansen \& Haaland, 2015; Hiim, 2015).

Results from this and other Norwegian curriculum research projects have fewer results concerning the apprenticeship period of VET, but it seems imperative for the apprentices who are learning to receive systematic theoretical education closely related to their work.

Results and main principles from this previous project are an important background in our new project on vocationally relevant curriculum. Epistemological analyses of how vocational knowledge is constituted and developed may provide a deeper understanding of the principles.

The question is: How can the students' opportunities - or lack of opportunities to develop vocational knowledge be understood in light of rationalist, pragmatic, and critical epistemology? I will start with a rationalist, technological concept of vocational knowledge and curriculum.

\section{A Rationalist Concept of Vocational Knowledge and Curriculum}

Problems of relevance in professional and vocational education have been analysed in the context of a rationalist, technological concept of knowledge (e.g. Dreyfus, 1991; Dreyfus \& Dreyfus, 1986; Molander, 1997; Schön, 1983, 1995). A technological concept of knowledge implies that knowledge is seen as depictions of given entities in the world, relating to each other through laws (Molander, 1997). The relationship between theory and practice is seen as a kind of one-to-one relationship between a map and a terrain. There is an understanding that generally given concepts and conceptual structures can be transferred through verbal formulations and then used in practice. This means that disciplinary theoretical knowledge (e.g. mathematics, physics, biology, psychology, or language) can first be learned at school and then applied in professional and vocational practice (Janik, 1996). The Norwegian $2+2-$ model is partly based on a rationalist understanding of vocational knowledge and curriculum. The model itself was more or less built on the assumption that theoretical knowledge can be learned at school the first two years, and then applied in vocational practice during the apprenticeship period. Results from the project mentioned earlier show that the separation of theoretical, disciplinary knowledge from practical skills and knowledge is problematic for the students and questioned by the vocational teachers (Hiim, 2015).

A technological concept of knowledge tends to imply a systematic separation between theoretical and practical arenas for learning and knowledge development, and between theoretical and practical subjects, and a domination of theory (Molander, 1997). This kind of separation and domination is seen in many VET models and curricula (Billett, 2011; Young, 2004). It usually leads to problems of relevance in the curriculum, as seen in 
the Norwegian model and the research presented above. A technological understanding of the relationship between theory and practice is also connected with a separation of professional or vocational practice and research (Janik, 1996). This separation tends to imply a lack of knowledge development, research, and educational literature based on professional vocational practice (Schön, 1983). A lack of systematic development of vocational language, concepts, and theory is a problem in many vocations. The education is forced to borrow concepts from other professional areas or from general theoretical disciplines in the curriculum that are not an integrated part of the knowledge base in the actual vocation.

The relevancy problems in Norwegian VET and corresponding problems in other VET models indicate that the curriculum is based on a one-sided and insufficient rationalist understanding of how vocational knowledge is constituted and developed. In the next section, I will investigate pragmatic perspectives on vocational knowledge and curriculum that are partly based on a critique of rationalism.

\section{Pragmatic Epistemological Perspectives on Vocational Knowledge and Curriculum}

Interpretations of pragmatic philosophy (e.g. of the late Wittgenstein, 2003; the early Heidegger, 1978; and Dewey, 2010) have inspired educators and theorists of professional and vocational knowledge (e.g. Dreyfus \& Dreyfus, 1986; Janik, 1996; Molander, 1997; Schön, 1983, 1988). Pragmatic epistemology raises questions concerning a conventional, rationalist conception of knowledge and knowledge transfer. The theorists named earlier have argued that a rationalist concept of knowledge is too limited for understanding professional and vocational knowledge and learning, and tends to oversimplify the relationship between theory and practice in a way that leads to problems of relevance in education. In my discussion of pragmatic perspectives on vocational knowledge and curriculum, I begin with some basic concepts from Wittgenstein and Heidegger. Then I investigate some key concepts from Dreyfus and Dreyfus' (1986) and Schön's (1983, 1988) theories on professional knowledge and education that can throw light upon how relevant VET curricula can be developed. I will try to show that there is a strong connection between epistemological concepts in Wittgenstein and Heidegger's philosophies and Dreyfus and Dreyfus' and Schön's theories on professional knowledge and education. The analysis of this connection may create a deeper understanding of Dreyfus and Dreyfus' and Schön's theories and of vocational knowledge and curriculum.

From a pragmatic perspective, life forms and practices are the foundations of experience and learning. Experience and language are seen as living, participating, involved activity whereby the use of words and concepts is woven into cultural and practical patterns (e.g. practical patterns as a nurse, a plumber, a health care assistant, etc.). Attention is directed towards different dimensions of knowledge. Vocational knowledge is constituted by complex wholes of physical, motor skills, intellectual understandings, emotions, values, and verbalised concepts. Contextual aspects of knowledge and learning are emphasised. The example and practical situations are of basic importance in pro- 
fessional and vocational learning and knowledge development (Janik, 1996; Molander, 1997). The focus on the practical situation, the example, and the multidimensionality of knowledge has important implications for the curriculum that I will come back to in subsequent sections.

\subsection{Vocational Knowledge and Curriculum in Light of Wittgenstein}

Based on interpretations of Wittgenstein's (2003) game metaphor, experience can be compared with games as a playful, living activity (see also Hiim, 2010; Janik, 1996; Molander, 1997). Experience and learning are processes that happen through participation rather than reception. A game has a point - a purpose. Engagement and understanding of the purpose is necessary to learn the game. To learn a game, one must be shown by someone who knows and can play it. Experience and learning happen through participation in something for which one sees the point and purpose. For instance - what is the social, cultural, and personal purpose of being a health care assistant, a florist, or a plumber? What are the basic tasks and social mandate?

The game metaphor implies that experience and learning can be understood as participating in life forms or games that are continually developed and changed (Molander, 1997). Words and concepts are woven into a life form or a context (e.g. the context as a plumber or a health care assistant). Understanding a concept means taking part in a context. Concepts (e.g. the concept "care for the patient") have meaning in a specific health care situation, related to other concepts, and the meaning of a concept varies with the context (Janik, 1996).

From Wittgenstein's (2003) perspective, experience and knowledge are constituted by actions, sensations, emotions, understanding, intentions, and language. Involvement, sensitivity, and instinct are as important as theoretical and intellectual reason. Seen from this angle, vocational knowledge is in our bodies, both in our way of watching and in the vocational culture.

Wittgenstein's (2003) holistic conception of knowledge emphasizes the situation as a unity of meaning and the importance of learning from examples. He points towards the necessity of participating in the "games" in which concepts are grounded (e.g. the game as a health care assistant or a plumber). A criterion for relevant curriculum in VET is that students have opportunities to participate in relevant practical situations and tasks that may serve as basic examples of professional practice (Hiim, 2013). A main challenge is creating paradigmatic examples from situations concerning vocational tasks and competences that constitute basic knowledge in the actual vocation (Janik, 1996). An important part of the cooperation between vocational teachers and instructors is to clarify basic functions and tasks in the actual vocation and relate them to authentic example situations in which students can be actively involved. The aim is to create a common understanding of core competences and needs for qualifications - a common understanding of the game, so to speak. To learn the actual vocational game, students must participate in real situations and be guided by experts. It is not enough to be told about or look at the game, as is often the case in school-based VET.

Wittgenstein (2003) rejects the idea that concepts can be defined by absolute general 
structures. Practical knowledge does not imply the application of theoretical definitions, concepts, or propositions in specific situations. It cannot be developed through applying general rules in particular cases (Janik, 1996). Relevance problems in vocational schoolbased education are connected with a lack of attention to how vocational concepts and knowledge are constituted through regular practical experience. Vocational students' lack of opportunities for this experience in Norwegian VET may be regarded as creating a major relevance problem in the curriculum.

\subsection{Vocational Knowledge and Curriculum in Light of Heidegger}

Based on Heidegger's (1978) workshop metaphor, experience can be compared with work in a workshop where everything has a function and an ultimate purpose (e.g. building doors to a house to protect people against weather and danger). From Heidegger's perspective, our use of things and concepts are always connected with intentions, functions, and contexts that are already in our existence and culture. Experience and learning primarily happen through participation in something, the point of which is clear to us - through projects. Experience always implies intentionality - a project, something we will, which means something (Janik, 1996; Molander, 1997). Experience and learning become explicit and conscious when we encounter a challenge or problem: a hammer that is too heavy, a patient who looks uncomfortable, etc. Discovering and framing problems that are experienced in concrete situations and contexts is a basic starting point for learning. Actions and concepts take on meaning through meaningful contexts in which we are involved (Dreyfus, 1991). The plumbing tools and concepts get meaning through the actual work situations and challenges. We learn through using and doing, through intentions related to involvement, feelings, and senses. Phenomena and concepts have meaning related to functions and tasks. We are absorbed in our practice, and then a problem arises. The challenges we face demand deliberation, reflection, new solutions and new knowledge. A criterion for relevant curriculum is that students have opportunities to participate in projects that mean something to them as future professionals, that is, projects whose purpose they understand, are involved in and from which they have the opportunity to solve authentic professional problems (Dreyfus, 1991). Our new curriculum project is aimed at investigating these opportunities.

\subsection{Vocational Knowledge and Curriculum in Light of Dreyfus and Dreyfus' Competence Model}

As we have seen in the sections above, a pragmatic epistemological understanding of vocational knowledge emphasizes that it is multidimensional, context bound and related to examples and challenges in concrete situations. In this section I will try to connect the epistemological analyses above with an investigation of Dreyfus and Dreyfus (1986) competence model, and see how the model can throw light upon VET curriculum.

A main idea in Dreyfus and Dreyfus' competence model is to warn against rationalist ideas that professional knowledge can be reduced to or governed by conventional instrumental theories, rules and procedures. Such ideas may lead to a theoretically and 
practically standardized curriculum where students lack the opportunities of varied experience and of developing their ability for exercising professional vocational judgement. We see such tendencies of standardization in Norwegian VET curricula, especially when it comes to formal assessment. According to Dreyfus and Dreyfus (1986), the reduction of vocational knowledge to standards may lead to professional stagnation.

The competence model shows the development of professional skills and knowledge occurring through a gradual move from novice to expert whereby a core aspect of the educational experience consists of practical exercise and realistic examples. Learning through exercise in practical situations necessarily includes senses, motor skills and feelings as well as intellectual understanding. Professional knowledge consists of a complex integration of knowing how and knowing that; it cannot simply be reduced to words:

The fact that you can't put what you have learned into words means that know-how is not accessible for you in the form of facts and rules. ... If you are a carpenter, you know how to use tools in a way that escapes verbalization (Dreyfus \& Dreyfus, 1986, pp. 14-15).

At the initial or novice level, we often learn by following simple procedures in standardised exercise situations. But at subsequent levels, which should be stimulated quickly, our learning takes place as a gradually more complex meeting with real situations where emotional involvement plays a major role. As tasks and situations become more and more extensive and complex, procedures and plans are gradually replaced by greater levels of situational adaption and professional patterns of reaction. Students' development of professional identity and engagement grows along with opportunities fostering responsibility in professional performance.

According to Dreyfus and Dreyfus (1986), expert knowledge is not characterised by procedures and calculated plans; it takes place in a more holistic way. Expertise means being able to "read" situations and to act quickly and intuitively (e.g. as a plumber, health care assistant, or nurse). It presupposes extensive, involved experience in many different situations and a great repertoire of skills. Dreyfus and Dreyfus' conception of professional knowledge implies that a main concern in relevant VET curricula is stimulating the development of "beginning expertise". An important principle is that students have opportunities to become involved in a considerable number of vocationally authentic, situational, and gradually ambiguous examples in placement periods and school workshops. Principles relating to tasks and assignments in the practice setting or school include ensuring they are different, complex, and varied, and that the students gradually acquire increasing levels of professional responsibility. Professional coherence between different tasks is essential. Authentic examples, coherence between tasks, and the development of beginning expertise can only be obtained through close cooperation between vocational schools and work enterprises. As we have seen, this kind of cooperation is limited in school-based Norwegian VET, as are students' opportunities to work with vocationally authentic examples.

From Dreyfus and Dreyfus' (1986) perspective, the curriculum should focus on the interpretation of practical situations rather than on theory in the first place. The ability 
to use former experience in problem-solving and to learn from practice needs to be stimulated. Discussions of different perspectives regarding professional tasks and basic interpretations of professional work (e.g. as a plumber or health care assistant) may stimulate students' learning from practice. Further discussions and interpretations of practical situations in the school workshop, in the workplace, and in the classroom will facilitate the development of professional vocational knowledge.

From a point of view inspired by Dreyfus and Dreyfus (1986), an important principle in vocational curriculum is to organize ongoing discussions to clarify what kinds of tasks and examples students should work with during their education to ensure relevance and progression. Tasks and assignments easily become rather accidental and governed by what happens from day to day, especially during the important placement periods. It should be emphasized that the point is not to define fixed standards for assignments and exercises, which would be contrary to Dreyfus and Dreyfus' epistemological ideas, but to see the clarification of tasks as a dynamic curricular process.

Dreyfus and Dreyfus (1986) do not say much about the concept of theory, but they see theoretical knowledge as a factor in explaining and criticising vocational performance. Formal theory should be taught after students receive practical experience and must be systematically related to professional tasks and functions. This means that theories should be integrated to explain and to provide perspectives on practical problems and solutions. The concept "vocational theory" was used earlier in Norway, and may be helpful as long as it is not interpreted as a one-sided instrumental concept. For Dreyfus and Dreyfus, a main issue is that professional and vocational knowledge is grounded in a variety of examples and cannot be reduced to instrumental prescriptions.

From a pragmatic point of view, Dreyfus and Dreyfus' (1986) competence model may be criticised for too strong an emphasis on standardised exercises in the initial phases of the professional learning process. It can be argued that students can be invited to be involved in simple but realistic tasks from the start. However, the model is clearly inspired by a pragmatic epistemological concept of professional knowledge, with its focus on the situation, the example, the tasks, the involvement, and the multi-dimensionality of knowledge, and with its scepticism towards standardization of the curriculum. The model is a system of ideas and principles concerning how vocational knowledge can be developed from beginner to expert level, and how the curriculum can be correspondingly organized.

\subsection{Vocational Knowledge and Curriculum in Light of Schön's Concept of a Reflective Practicum}

Schön (1983) is very critical of a technological, rationalist view of professional knowledge and education that implies that professional knowledge and activity "consist in instrumental problem-solving made rigorous by the application of scientific theory and technique" (Schön, 1983, p. 21). He argues that the educational system is strongly influenced by a technological concept of knowledge, and that the development of professionalism has been poor in modern educational systems. Opportunities for practicebased learning remain limited, workshop exercises are overly structured, and there is 
a lack of theory development and research based on actual vocational and professional practices. As mentioned above, these are all problems in Norwegian VET that need to be addressed and investigated. In his critique, Schön (1983) argues that practical tasks (e.g. as a nurse or plumber) change all the time and are characterised by complexity, uncertainty, and value conflicts that cannot be reduced to technical standards. Professional knowledge is multidimensional, constituted of skills related to our senses, values, feelings, understanding, and verbalised concepts. Factors relating to senses and skills cannot be reduced to words, but Schön emphasizes that words play an important role in professional vocational work and learning processes.

In his studies, Schön demonstrates how professionals carry out reflective conversations within the situation, a practice that he calls reflection-in-action (Schön, 1983). The professional worker acts, thinks, talks, and learns. The process can be compared to a game in which each move has consequences for the next, and each move is a kind of experiment. We try out how our practice (e.g. the construction or the nursing process) can be performed as well as possible. The trying-out is connected with a conceptual framing and understanding of the situation, which may be expressed through a professional theoretical perspective. The role of vocational teachers and instructors is to guide and advise students in this process. Vocational knowledge is developed through reflection-in-action and professional theoretical framing of situations. It is developed through critique of good work and experiments with alternatives.

Schön emphasises the value of what he calls a reflective practicum $(1983,1988)$, which means a simulated professional world in the form of a workshop or a clinic where students can experiment and reflect in realistic situations. Real work practice should also function as a reflective practicum, whereby students can experiment and reflect on a wide range of situations under safe conditions.

Schön is adamant about the importance of stimulating reflection-in-action in the education of practitioners and sees this kind of reflection as analogous to a researcher's attitude to practice:

When someone reflects-in-action, he becomes a researcher in the practice context. He is not dependent on the categories of established theory and technique, but constructs a new theory for the unique case .... He does not separate thinking from doing (Schön, 1983, pp. 68-69).

Not separating thinking from doing and theory from practice is a core issue in Schön's conception of professional and vocational knowledge. He uses the concept of knowing-inaction to express the unity of thinking and doing. This unity, and the multidimensionality of vocational knowledge, implies that this kind of knowledge is expressed through complex wholes of manual skills, intellectual reason, and value judgments. A relevant curriculum is a curriculum that provides the students with opportunities to develop and express all dimensions of knowledge in the actual vocation. Also, when it comes to assessment, holistic vocational knowledge should be evaluated; assessment should not be limited to fragmented verbal, disciplinary, or theoretical knowledge, as is often the case.

Schön also argues for the importance of practice-based research where practitioners 
(e.g. nurses or teachers) contribute to the development of professional concepts relating to professional examples (Schön, 1991). The need for practitioner research can be seen in relation to a traditional distinction between real professions, semi-professions and vocations. The distinction, which is still widely used, implies that real professions have theory and research directly linked to them, semi-professions must borrow theory from real professions and from academic disciplines, and vocations do not need theory and research because they just demand practical, manual skills (Schön, 1983; Smeby, 2015).

An understanding that vocational competence mainly consists of manual skills is highly dubious in a modern, technological, and complex society where a considerable number of vocational tasks require advanced practical and theoretical knowledge. One of the reasons for increasing the school-based component of vocational education is the recognition that vocational knowledge and high-level competence include theory. When Schön (1983) points to the distinction between professions, semi-professions, and vocations, he draws attention to a lack of relevant research and theory in the latter two, which leads to problems of relevance. Theoretical concepts grounded in actual professional practice are important in all professions and vocations in modern society. They concern descriptions of how and explanations of why, and offer broader social perspectives on vocational practice. From this point of view, systematic, practice-based development projects and research are needed in all vocations to strengthen the knowledge base and the curriculum in the actual vocations.

Based on Schön's $(1983,1988)$ ideas, it seems reasonable to say that an important aspect of curriculum development in VET is to relate concepts and theories that are borrowed from the professions or from academic disciplines systematically to actual vocations. Theories and disciplines should be integrated through a focus on essential vocational tasks. The curriculum should not be split into disciplines and subjects separated from vocational functions, as is often the case.

Schön's concepts of knowing-in-action and reflection-in-action point towards how a relevant curriculum in VET can be developed through a reflective practicum, where knowing and action are integrated. The reflective practicum contains authentic practical situations, examples, and multidimensional tasks that students are involved in, where they can experiment with and reflect on problem definitions and problem-solving.

Pragmatic epistemology has been criticised for an overly one-sided focus on existing traditions of practice, with insufficient attention paid to normative aspects and questions of power. This critique will be discussed in the next section.

\subsection{Vocational Knowledge and Curriculum in Light of Habermas}

There may be a tendency to conceive of established vocational and professional knowledge and traditions as a given, rather than as an expression of social norms and values that may be changed (Habermas, 1980). In this way, the apprenticeship tradition in vocational education has been partly characterised by a relatively authoritarian transference of traditions, a lack of co-influence in the learning process, and a lack of critique and development.

As mentioned earlier, there is also a relatively strong tendency in our society to reduce 
different types of practice, in technical as well as in social vocations, to instrumental actions and skills that are primarily evaluated on the basis of demands for efficiency (Nielsen, Nielsen,\& Munch-Madsen, 2010; Sennett, 2008). In a one-sided instrumental understanding of social and professional activity and knowledge, the evaluation of skilled craftsmanship, care for patients, and learning is reduced to a question of efficiency related to given, measurable standards. Habermas' (1999) concern in the theory of communicative action is to create a basis for the critique and democratic change of social practice. All vocations, technical as well as social, have a social element of norms and values that constitutes parts of their vocational knowledge.

Communicative competence (Habermas, 1999) means the ability to judge, in fields such as nursing, construction, and floristry: Is what is done and said effective? Is it in accordance with factual knowledge in the actual field? Is it understandable to those involved (i.e., patients, customers, clients, colleagues)? Do those involved have an opportunity to express themselves sincerely about what happens? Are actions and statements just, and in accordance with the ethics and social mandate of the vocation? From a critical perspective, these criteria represent important aspects of the VET curriculum. Students participating in vocational education must be stimulated to raise these questions when they plan, carry out, and evaluate their work, and be urged to answer them in collaboration with their patients, clients, and colleagues.

Abilities relating to democratic, cooperative reflection, critique, and change are an important part of skilled workers' professional competence, whether they work as health care assistants, construction workers, electricians, or workers in other vocational fields. A high degree of standardisation in the organisation of modern work life - for instance - in health care work, tends to eliminate much of the professional's responsibility for planning, carrying out, and evaluating work. The result may be a kind of de-professionalization where vocational competence becomes less varied and independent (Nielsen et al., 2010; Sennett, 2008). From a critical epistemological perspective, relevant vocational curricula are based on an understanding of vocational knowledge that also includes cooperation, creativity, independence, and ability to change. An important principle is to stimulate these competencies through democratic educational processes whereby students have co-influence in their own learning process.

\section{Concluding Discussion: How can Curriculum Relevance in VET be Improved?}

In this final discussion, I will conclude what we have learned about improving curriculum relevance from the epistemological analyses of vocational knowledge in the previous sections. Relevant curriculum can be defined as a curriculum that provides students with the opportunity to develop vocational knowledge in their chosen occupations. The epistemological analyses and results from previous research on the Norwegian VET curriculum indicate that unclear conceptions of what vocational knowledge is and how it is developed are problems in Norwegian VET and possibly in other VET programs. The analyses show that problems in the $2+2$ model related to a split between learning arenas, 
subjects, and theory and practice are connected with a rationalist, technological concept of knowledge that has, to a great extent, dominated our educational system. From a rationalist, technological epistemological perspective, professional vocational knowledge concerns the application of theory and technical procedures that can be learned before practice (Molander, 1997). Theoretical knowledge is separated from, and seen as superior to, practical knowledge (Janik, 1996). Results from previous research show that, according to VET teachers, practice in the form of placement periods has a low status and is not prioritized (Hansen \& Haaland, 2015; Hiim, 2015).

A technological, rationalist understanding of knowledge is expressed through the separation of theoretical and practical subjects in the formal curriculum frameworks; there are a lack of opportunities for work life practice during the first two years, separation of theoretical and practical subjects in the timetables of the schools, forms of assessment that prioritize verbal and written knowledge, a lack of cooperation between vocational and academic teachers, and so on (Hiim, 2013). There is also a tendency to see vocations as crafts that do not rely on theoretical knowledge; from this perspective, cooperation between schools and work life is not necessary. These kinds of ideas and practices are often taken for granted and can be very difficult to change.

Results from previous research on Norwegian VET curricula, however, indicate that many teachers and students do not find the curriculum meaningful, and do not think that it gives students the opportunity to develop vocational knowledge. These results also indicate that work life practice in the school-based part is essential to students' learning, and should be the core of the curriculum that all subjects are systematically related to (Hiim, 2013, 2015; Hansen \& Haaland, 2015). Still, there is a need for more research here (see also Gessler \& Howe, 2015). I have tried to show how analyses of vocational knowledge based on pragmatic and critical epistemologies can contribute with an understanding of why a more holistic, integrated and practice based curriculum should be developed, and how. The development and investigation of this kind of curriculum is a main issue in our new project.

A pragmatic concept of vocational knowledge, based on interpretations of Wittgenstein (2003) and Heidegger (1978) emphasises that our experience and learning are grounded in life forms and practices, and eventually vocational practices. Experience, learning, and knowledge development happen through participation in practices where intentions, concepts, and values are woven into professional vocational patterns. Professional vocational experience and knowledge is multi-dimensional, and it is constituted by complex wholes of skills related to senses, values, feelings, understanding, and verbal concepts. It is contextual, connected with various examples and situations, and has no absolute concepts. It has a purpose connected with a vocational practice, and with intentions, values, and responsibilities embedded in the practice (Janik, 1996; Molander, 1997).

Vocational knowledge concerns problem-solving in a variety of situations. This kind of knowledge is also intuitive, and demands abilities in situational judgement based on experiences from many different situations. Ethical judgment and democratic cooperation are important aspects of vocational knowledge, which also includes insight into the social and vocational mandate, and ability to critically judge norms and traditions. The last points are emphasized in critical epistemology (Habermas, 1999; Sennett, 2008). 
Professional vocational knowledge is expressed in many forms - manual and technical skills, intellectual and verbal reasoning, and action - while it is also holistic. It is much more complex than a "sum" of general theoretical and technical procedures to be applied in specific situations. Dreyfus and Dreyfus (1986) and Schön $(1983,1988)$ share these basic pragmatic ideas of how vocational knowledge is constituted, and both emphasize the importance of the practice traditions, the multi-dimensionality, the context, the examples, the situations, and the participation. Both criticize the split between theory and practice, the simplistic ideas of transference, and the tendencies of standardization in a technological, rationalist understanding of vocational knowledge. The question is: How is this kind of knowledge developed? What kind of curriculum is needed?

From a pragmatic epistemological perspective, guidance on choice of occupation can be helping the students to choose their "game" and main purpose of their education. In "Democracy and Education", Dewey (2010) emphasizes that choice of occupation is an existentially very important matter: "To find out what one is fitted to do and to secure the opportunity to do it is the key to happiness" (Dewey 2010, p. 308). Results from the previous project on curriculum research mentioned herein indicate that guidance from experienced vocational professionals, as well as opportunities for authentic work experience early in the school-based programme, are important for students' decisionmaking. Early work life practice is necessary to give the students a basic understanding of what a vocation is about and to understand its purpose (Hiim, 2013). From a pragmatic perspective, work life practice is the centre of the curriculum that all subjects, disciplines, and concepts must be clearly related to. Dreyfus and Dreyfus (1986) as well as Schön $(1983,1988)$ strongly emphasize realistic professional tasks as the core of professional and vocational curriculum. This means that cooperation between school and work life is a main principle in relevant VET curricula.

Dreyfus and Dreyfus' competence model can help in clarifying stages of progression in practical vocational tasks from simple to more complex situations, gradually demanding independent responsibility. Both Dreyfus and Dreyfus (1986) and Schön (1983) argue that variation in tasks, situations, and examples is crucial for the students' opportunities to develop robust vocational concepts, and should be encouraged in the curriculum. Variation is necessary to see similarities and differences between concepts and learn to use them adequately. The importance of problem-framing as well as discussions of different perspectives on vocational challenges is also emphasized by the authors. Problem-framing and discussion should be related to different explanations and different theories concerning the actual problem, as well as to students' former experiences. The aim is for students to learn that vocational situations and problems can be ambiguous, and that there may be many ways of understanding the challenges.

Schön $(1983,1988)$ is especially concerned with the importance of verbal reflection in the development of professional knowledge. A reflective practicum is a place: a school workshop or a workplace where students have opportunities and room to experiment with, reflect on, explain, and discuss realistic work performance under safe conditions. A reflective practicum is a place to investigate and research vocational practice individually and collectively, in order to develop individual and collective multidimensional vocational knowledge. 
The results of the epistemological analyses indicate that a relevant curriculum in VET is a curriculum where authentic work practice is the centre, and that all content is related to and integrated with that centre. In Norwegian VET, this would suggest a move towards stronger possibilities for students to choose and specialize in a vocation quite early. Within the $2+2$ model, regular placement periods in vocational firms that are systematically planned, followed up on, and worked on afterwards at school seems crucial. School subjects should be related systematically to, and integrated with, work practice, and assessment forms must allow and stimulate the expression of multidimensional vocational knowledge.

Empirical research in our project will be inspired by the epistemological analyses and principles that have been presented in this article. The aim is to find out more about how different stakeholders experience the curriculum, and how a more relevant curriculum can be developed in different programs. Curriculum research in VET is limited, and there is a need for more research in this field. I hope that the epistemological perspectives in this article can also inspire other researchers. 


\section{References}

Billett, S. (2011). Vocational education. Purposes, traditions and prospects. Dordrect: Springer.

Dahlback, J., Hansen, K., Haaland, G., \& Sylte, A.-L.(2011). Yrkesdidaktisk kunnskapsutvikling og implementering av nye læreplaner. (KIP). [The development of new didactic knowledge and the implementation of a new curriculum]. Report, R.U.1/2011, Oslo \& Akershus University College, the Department of Vocational Teacher Education.

Dewey, J. (2010). Democracy and education. Boston: MobileReference.com.

Dreyfus, H. (1991). Being-in-the-world: A commentary on Heidegger's being and time, Division 1. Cambridge, Massachusetts, London: The MIT Press.

Dreyfus, H., \& Dreyfus, S. (1986). Mind over machine. The power of human intuition and expertise in the era of the computer. New York: Free Press.

Gessler, M., \& Howe, F. (2015). From the reality of work to grounded work-based vocational education and training. International Journal for Research in Vocational Education and Training , 2(3), 214-238. doi: 10.13152/IJRVET.2.3.6

Habermas, J. (1980). Teorier om samfund og sprog [Theories on society and language]. København: Gyldendal.

Habermas, J. (1999). Kommunikativ handling, lov og rett [The theory of communicative action]. Oslo: Tano Aschehoug.

Hansen, K., \& Haaland, G. (2015). Utfordringer i norsk yrkesopplæring. [Challenges in Norwegian vocational education]. In Hansen, K., Løkensgard-Hoel, T. \& Haaland, G. (Eds.). Tett på yrkesopplæring [Close to vocational education]. Bergen: Fagbokforlaget, 19-49.

Heggen, K., Smeby, J.-C., \& Vågan, A. (2015). Coherence: A longitudinal approach. In Smedby, J.-C., \& Suthpen, M. (Eds.). From vocational to professional education. London: Routledge, 70-88.

Heidegger, M. (1978). Being and time. Oxford: Blackwell.

Hiim, H. (2007). A Strategy for Practice Based Education and Research, built on experience from educating vocational teachers. In Ponte, P. \& Smith, B. (Eds.). The Quality of Practitioner research. Rotterdam: Sense Publishers, 97-114.

Hiim, H. (2010). Pedagogisk aksjonsforskning. Eksempler, prinsipper og kunnskapsfilosofisk grunnlag. (Pedagogical Action Research. Examples, principles and epistemology). Oslo: Gyldendal Akademic Press.

Hiim, H. (2013). Praksisbasert yrkesutdanning [Practice based vocational education]. Oslo: Gyldendal Akademisk.

Hiim, H. (2015). Kvalitet i yrkesutdanningen. Resultater fra et aksjonsforskningsprosjekt om yrkesutdanningens innhold og struktur [The quality of curriculum in VET. Results from an action research project on content and structure in VET]. Norsk Pedagogisk Tidsskrift [The Norwegian Journal of Pedagogy]. Nr. $2 \backslash 3$ 2015, 136-148.

Hiim, H. (2016). Educational Action Research and the development of Professional Teacher Knowledge. In Gunnarsson, E., Hansen, H. P., Steen Nielsen, B., \& Sriskandarajah, N. (Eds.). Action Research for Democracy. London: Routledge, 147-161. 
Janik, A. (1996). Kunskapsbegreppet i praktisk filosofi [The concept of knowledge in practical philosophy]. Stockholm: Symposion.

Kemmis, S. (2012). Researching Educational Praxis: Spectator and Participant Perspectives. British Educational Research Journal 38 (6), 885-905.

Molander, B. (1997). Arbetets Kunskapsteori [The epistemology of work]. Stockholm: Gotab.

Nielsen, L. D., Nielsen, K. A., \& Munch-Madsen, E. (2010). Fleksibilitet, flyktighet og frirum - en kritisk diagnose av det senmoderne arbeidsliv [Flexibility, volatility and free space - A critical diagnosis of late modern work life]. Roskilde: Roskilde University Press.

Nyen, T., \& Tønder, A. H. (2012). Fleksibilitet eller faglighet? En studie av innføringen av faget prosjekt til fordypning i Kunnskapsløftet [Flexibility or vocational focus? A study of the new subject "vocational choice" in the Knowledge Promotion Reform]. Fafo-report, 2012, 47.

Schön, D. (1983). The reflective practitioner. New York: Basic Books.

Schön, D. (1988). Educating the reflective practitioner. San Fransisco: Jossey-Bass.

Schön, D. (1991). The Reflective Turn. Case studies in and on Educational Practice. New York: Teachers College.

Schön, D. (1995). Knowing-in-Action. The new scholarship requires a new epistemology Change. November to December, 2734.

Sennett, R. (2008). The craftsman. New Haven: Yale University Press.

Smeby, J-C. (2015). Academic drift in vocational education? In Smedby, J.-C., \& Suthpen, M. (Eds.). From vocational to professional education. London: Routledge, $7-25$.

Vibe, N., Frøseth, M. W., Hovdehaugen, E., \& Markussen, E. (2012). Strukturer og konjunkturer. Evaluering av Kunnskapsløftet. Sluttrapport fra prosjektet "Tilbudsstruktur, gjennomføring og kompetanseoppnåelse i videregående opplæring" [Structures and economic cycles. Evaluation of the knowledge promotion reform. Final report from the project "Structures and competence achievement in high school education"]. Report 26/2012. NIFU.

Wittgenstein, L. (2003). Filosofiske unders $\varnothing$ kelser [Philosophical investigations]. Oslo: De norske bokklubbene.

Young, M. (2004). Conceptualizing vocational knowledge: Some theoretical considerations. In Rainbird, H., Fuller, A., \& Munro, A. (Eds.). Workplace learning in context. London: Routledge, 186-200.

Zeichner, K. (2002). Educational Action Research. In P. Reason \& H. Bradbury (Eds.), Handbook of Action Research (273-284) . London: Sage. 


\section{Bibliographical Note}

Dr Hilde Hiim is a professor at the Institute of Vocational Teacher Education at Oslo and Akershus University College, Norway. Her research interests focus on vocational knowledge, curriculum development in vocational education and educational action research. 